\title{
PRIVATISASI BUMN : MODEL DAN PILIHAN KEBIJAKAN DALAM MEWUJUDKAN KEMANDIRIAN EKONOMI NASIONAL
}

\author{
Hilmi Rahman Ibrahim \\ Dosen FISIP, Universitas Nasional Jakarta \\ hilmi_rahman69@yahoo.com
}

\begin{abstract}
ABSTRAK
Pembangunan nasional merupakan keniscayaan dalam mengimbangi perkembangan, kemajuan dan persaingan pembangunan antar negara. Bagi negara berkembang termasuk Indonesia, pembangunan diarahkan untuk memperkuat ekonomi nasional dalam mewujudkan kemandirian ekonomi. Kemandirian ekonomi dapat terwujud bila produksi dan kebijakan industrialisasi dilakukan secara efeisien diimbangi dengan pola ditribusi barang dan pemerataan eknomi yang dapat menjangkau masyarakat secara keseluruhan. Distribusi ekonomi diperlukan melalui ketersediaan infrastruktur yang memadai didukung dan oleh ketersediaan anggaran yang bersumber dari dalam negeri. Salah satu sumber pembiayaan yang perlu dipertimbangkan adalah melalui kebijakan privatisasi dengan pengembangan model pembiayaan melalui pemanfaatan aset BUMN yang cukup besar
\end{abstract}

Kata kunci : Privatisasi, Model, Pembiayaan Pembangunan

\section{ABSTRACT}

National development is enivetable for Indonesia to compete with other nations. As a developing country, Indonesia considers its development that is oriented towards selfreliane of its economy. This can be achieved by efficiency in the production and sound policy industrialization and distribution of goods and services; along with equal opportunity for vast people to involve in the economic activities. All these are likely to be materialized when supported by sufficient infrastructure financed by domestic sources of fund. One source crucial to it is the one coming from BUMN or state-owned enterprises. The paper shall look into the policy of privatization of BUMN and the crucial issue of self-relianace of Indonesia's economy. The finding of the study is that given the presence of several optins of privatization models, Indonesia should adopt anoption that comparatively fit the growth as well as the economic well-being of vast people.

Keywords: models of privatization, BUMN, development

\section{A. Pendahuluan}

Meningkatnya beban negara dalam sektor pembiayaan pembangunan, mendorong pemerintah melakukan pinjaman luar negeri dalam rangka penyediaan modal kerja pembangunan. Kebijakan ini dilakukan pemerintah untuk memastikan keberlanjutan pembiayaan pembangunan, terutama di sektor infrastruktur. 
Pemerintahan dibawah rezim Jokowi- JK dalam periode 2014- 2019, sedang menargetkan pembangunn infrastruktur besar-besaran baik infratsruktur jalan, bandara, pelabuhan, pembangkit tenaga listrik maupun infrastruktur dasar lainya.

Prioritas pembangunan infrastruktur yang dijalankan oleh pemerintah saat ini, bukan tanpa alasan, selain untuk memenuhi harapan publik dan syarat investasi, dalam mengejar ketertinggalan Indonesia dibidang penyediaan infrastruktur, bila dibandingkan dengan negara- negara tetangga masih sangat tertinggal, juga dalam rangka memperkuat integrasi ekonomi domestik, untuk mengurangi biaya distribusi arus barang yang selama ini dianggap terlalu mahal dan tidak kompetitif dalam memperkuat kebijakan industrilialisasi.

Untuk mendukung pemerintah, maka pencarian alternatif pembiayaan menjadi penting, tidak semata- mata mengandalkan utang luar negeri yang dalam 3 tahun terahir pemerintah perlu mencari skema atau mengembangankan model pembiayaan alternatif, salah satunya adalah melalui mekanisme privatisasi BUMN.

Privatisasi BUMN yang dimaksudkan adalah memberi kesempatan kepada pemerintah untuk melepas sebagian besar atau sebagian kecil saham BUMN stratgis yang memiliki ekternailtas kecil, namun dari sisi keuntungan memiliki potensi yang masih sangat baik. Privatisasi BUMN sebagai alternatif pembiayaan pembangunan sudah banyak dikembangkan oleh negara maju di dunia maupun negara- negara berkembang. Tulisan ini selain memberikan batasan dan pengertian BUMN juga memberikan beberapa model privatisasi BUMN yang dilakukan dibeberapa negara maju dan berkembang serta pilihan kebijakan yang dapat menjadi model atau skema pembiayaan

Bagi pemerintah, pengembangan model pembiayaan melalui privatisasi BUMN bukan hal yang baru, namun saatnya pemerintah mengembangkan model privatisasi terutama pembiayaan pembangunan jangka pendek, untuk menghindari pinjaman dan ketergantungan utang luar negeri dari lembaga keuangan internasional.

\section{B. Privatisasi : Pengertian dan Pilihan Kebijakan}

Privatisasi dalam berbagi litelatur berarti mengurangi peran pemerintahan dalam berbagai kegiatan yang selama ini menjadi bagian dan tugas serta fungsi pemerintah melalui pengoperasian BUMN-nya. Kegiatan privatisasi yang dilaksanakan oleh pemerintah merupakan upaya dalam mendorong efesiensi dan mewujudkan terselenggaranya pemerintahan yang baik. Di samping itu, privatisasi juga dapat menjadi model alternatif pembiayaan untuk memenuhi kebutuhan anggaran dalam kegiatan pembangunan nasional.

Privatisasi menjadi strategi pemerintah dalam menghindari intervensi kekuasaan politik yang selama ini menjadi "ancaman" bagi perusahaan milik negara (BUMN). Adanya kemungkinan dan potensi keterlibatan partai politik dalam penempatan orang per orang dalam struktur direksi BUMN merupakan salah satu indikasi betapa BUMN di Indonesia cukup rawan terhadap ancaman dari berbagai kelompok kepentingan. Terjadinya perbedaan pendapat dan dukungan terhadap setiap calon oleh kelompok politik tertentu, yang akan menduduki posisi puncak disalah satu BUMN, merupakan ajang perebutan lahan di BUMN yang sangat rentan. 
Upaya pembenahan BUMN, khususnya melalui privatisasi, dilaksanakan karena adanya tiga faktor utama, yaitu, Pertama, penerimaan hasil ekspor non migas belum sepenuhnya dapat menggantikan kemerosotan penerimaan negara di sektor migas. Situasi ini dipersulit dengan adanya kewajiban membayar bunga dan cicilan hutang luar negeri yang terus menigkat. Meningkatnya kebutuhan dana untuk pembangunan di berbagai sektor ekonomi, mendorong pemerintah memberikan bantuan dalam bentuk penyertaan modal negara (PMN) kepada BUMN, Padahal semestinya BUMN dapat membiayai dirinya sendiri, dan memberikan kontribusinya kepada anggaran pemerintah dalam bentuk deviden dan pajak pendapatan badan. Kedua, kebijakan liberalisasi ekonomi yang dilaksanakan pemerintah, yaitu dengan memberi peluang yang lebih besar kepada usaha swasta, telah membawa konsekuensi semankin tumbuhnya swasta dalam negeri dan swasta asing menjadi pesaing BUMN. Ketiga, tekanan dari perdagangan bebas dunia mengharuskan BUMN mampu membuat hasil produksi dengan basis efisiensi dan kemampuan bersaing.

Pada dasarnya BUMN yang di privatisasi lebih banyak disebabkan karena kinerja memburuk yang berdampak pada kendala keuangan yang dihadapi oleh masing-masing perusahaan. Hal ini dikemukakan pula oleh Russel yang menyatakan bahwa privatisasi diperlukan antara lain disebabkan oleh adanya tekanan fiskal, kesulitan untuk memenuhi persyaratan permodalan sebagai akibat dari keterbatasan pinjaman, dan keingginan untuk mengurangi pinjaman luar negeri. Di samping itu, adanya tekanan dari organisasi internasional, seperti Bank Dunia dan Dana Moneter Internasional, serta dari masyarakat bisnis setempat, memberikan keyakinan bahwa privatisasi akan dapat menimbulkan rangsangan untuk pembaharuan. (Russel,1993:6).

Privatisasi telah menjadi kebijakan ekonomi di berbagai Negara maju maupun Negara berkembang. Tekanan ekonomi dunia yang semakin kompleks, terutama dalam menghadapi persaingan yang semangkin tajam di era globalisasi, mendorong pemerintah meningkatkan efesiensi di segala bidang. Dalam kaitan ini, privatisasi merupakan salah satu solusi untuk memecahkan persoalan ekonomi utang luar negeri .

Privatisasi merupakan pengalihan sebagian atau keseluruhan asset dan kontrol BUMN kepada swasta. Melalui privatisasi akan terjadi sinergi antara efisiensi, kompetisi dan laba. Efisiensi merupakan suatu aksi dalam meminimalkan input atau biaya dalam memperoleh output yang ditetapkan. Sedangkan kombinasi antara kekuatan bersaing dan upaya memaksimalkan keuntungan memberikan motivasi atau tekanan kepada pengelola perusahaan untuk selalu menjaga efisiensi (Ruru,1997:7).

Savas menyatakan bahwa privatisasi adalah kegiatan untuk mengurangi peranan pemerintah, atau meningkatkan peranan dari sector swasta di dalam suatu kegiatan atau dalam kepemilikan modal (the act of reducing the role of government, or increasing the role of private sector, in an activity or in the ownership of assets) ( Savas, 1987:11). Pengertian yang dikemukakan oleh Savas senada dengan pendapat dari Attiat F. Ott dan Keith Hartley yang menyatakan bahwa privatisasi merupakan kebijakan untuk : 
" to reduce both the size of the public sector through denationalization, and public sector borrowing. In other chases, privatization policy has been associated with a desire for wider share ownership and the creation of a share-owning democracy." (Hartley, 1991:12)

Dari pengertian tersebut menunjukkan bahwa melalui privatisasi, pemerintah tidak lagi memiliki seluruh asset perusahaan atau melaksanakan seluruh kegiatan yang selama ini dilaksanakan sendiri, tetapi telah menyerahkan sebagaian dari tugas dan fungsinya kepada sektor swasta. Dalam berbagai bentuk privatisasi yang dilakukan di negara-negara maju, diarahkan untuk mencapai tujuan-tujuan tertentu. Salah satu tujuannya adalah untuk mempromosikan kompetisi dan peningkatan efesiensi di sebuah perusahaan. Tujuan-tujuan khusus lainnya yang dapat disebutakan antara lain promosi kepemilikan saham yang luas, baik pekerja maupun masyarakat, peningkatan daya kompetisi, kemajuan inovasi tehnik serta pemecahan hambatan antar pekerja dan manajemen.

Di Indonesia privatisasi dalam beberapa hal diarahkan untuk mencegah campur tangan dari berbagai kelompok kepentingan. Karena itu salah satu prinsip dasar dari program privatisasi adalah mengedepankan transparansi dalam mengambil keputusan. Prinsip ini dijalankan dalam kaitan dengan pasar modal, yang akan menghasilkan efesiensi keuangan.

Di Inggris misalnya sebagai salah satu Negara yang banyak melaksanakan program privatisasi, dalam menjalankan kebijakan privatisasi pada industri selalu mendasarkan kepada tiga hal :

Pertama, perusahaan diteliti dan dimintakan persetujuan ke parlemen. Struktur peraturan juga perlu dikembangkan untuk melindungi tujuan nasional.

Kedua, Restrukturisasi keuangan perusahaan agar kondisi perusahaan untuk bertahan dan berkembang di sector swasta dapat dipastikan.

Ketiga, Jika pasar sedang booming maka perusahaan dijual dengan harga terbaik menurut kepentinagn Negara ( biasanya merupakan kompromi antara harga tertinggi dan penyebaran kepemilikan secara optimum ).

Dalam berbagai studi kepustakaan yang ada, privatisasi seringkali di konotasikan sebagai :

1. Pengembalian perusahaan Negara kepada sector swasta

2. Kontrak jasa kepada sector swasta

3. Pembebasan dalam arti kompetisi dan

4. Deregulasi

Terhadap pengalihan kepemilikan dari pemerintah kepada swasta Peacok berpandangan bahwa privatisasi sebagai pemindahan industri dari milik pemerintah ke sektor swasta yang berimplikasi pada peralihan saham dominan dalam pemilikan aktiva ke pemegang saham swasta. Sementara itu Beesley dan Littlechild ( Model Pengelolaan Privatisasi : 26-27). Berpandangan bahwa privatisasi diartikan sebagai pembentukan perusahaan. Company Act, bahwa penjualan yang berkelanjutan sekurang-kurangnya sebesar $50 \%$ dari saham pemerintah ke pemegang saham swasta. 
Pelaksanaan privatisasi di berbagai Negara merupakan penguatan pasar di dalam struktur perekonomianya. Privatisasi merupakan upaya mengembalikan aktivitas perekonomian kepada sector swasta dengan memperkecil campur tangan pemerintah dalam perekonomian nasional. Oleh karena itu, privatisasi dapat dipandang sebagai salah satu instrument dalam mewujudjan perbaikan ekonomi yang lebih luas, mencakup deregulasi dan liberalisasi.

Dengan privatisasi, maka segala campur tangan pemerintah dikurangi dan hambatan-hambatan dalam industri dan perdagangan dihilangkan sebagai bagian dalam mewujudkan efisiensi pasar dan daya saing perekonomian secara menyeluruh. Dalam pengertian yang lebih spesifik, privatisasi merupakan proses pengalihan BUMN komersial, kegiatan atau kekayaan produktif pemerintah menjadi pemilikan atau pengendalian swasta, baik secara keseluruhan, sebagian besar, atau sebagian kecil.

Privatisasi bukan merupakan hal yang mudah untuk dilaksanakan, karena berbagai kelemahan yang melekat di sebagaian perusahaan negara atau BUMN. Selain itu keberadaan dalam kepemilikan atau pengendalian dilakukan oleh pemerintah. Oleh karena itu, sebelum dilakukan privatisasi, maka terlebih dahulu diawali dengan proses restrukturisasi secara keseluruhan, baik dari segi hokum, keuangan, maupun segi budaya dan sikap kerja. Langkah ini ditempuh agar perusahaan tersebut memiliki nilai tambah (Value added).

Dalam rangka perbaikan struktur perekonomian nasional diperlukan penyesuaian (structural adjustment) yang mencakup berbagai perbaikan kebijakan ekonomi mikro dan perubahan kelembagaan untuk menghapusakan inefisiensi dan menjamin tingkat pertumbuhan yang memadai. Kebijakan tersebut adalah liberalisasi perdagangan, privatisasi perusahaan negara dan sektor swasta dengan pola kemitraan dan swadana serta deregulasi sektor ril. Kebijakan privatisasi sebenarnya merupakan langkah untuk meringankan beban pemerintah yang terlalu berat, karena itu perlunya mengurangi campur tangan pemerintah di dalam menjalankan usahanya dari pemerintah kepada pihak swasta, hal ini berarti masyarakat publik dapat meningkatkan partisipasinya di dalam pembangunan ekonomi, Savas (1987 : hal 3 ) mengemukakan :

"Privatization is the act of reducing the role of Goverment, or increasing the role of the private sector, in an activity or in the ownership of assets"

Bahwa privatisasi merupakan upaya dalam mengurangi campur tangan pemerintah dengan meningkatkan peranan kepada sektor swasta melalui kepemilikan aset. Jika pemerintah terlalu banyak bergerak disektor ekonomi, maka akan mengakibatkan terjadinya ketidakefisienan dalam sistem perekonomian nasional. Ketidakefisienan dalam arti ketidakmampuan pemerintah dalam menata atau mengalokasikan sumber daya yang tersedia, baik yang menyangkut sumber daya manusia, maupun sumber daya keuangan. Oleh karena itu, efisiensi menjadi masalah yang sangat penting mengingat terbatasnya sumber-sumber daya tadi.

Lebih lanjut Ernest \& Young mengemukakan bahwa privatisasi mempunyai arti yang lebih luas dari pada hanya mengurangi peranan pemerintah dan peningkatan peranan swasta dalam sektor ekonomi. 
"Privatization means more than the sale of ailing public companies at fire sale prices. Privatization can be defined broadly as the transfer or sale of any asset, organization, function, or activity from the public to private sector. As such in addition to the sale of publicy owned assets, the term 'privatization' also applies to join public-private venture, concession, leases, managemen contract, as well as to some specialized instruments, such as build-ownnoperate and transfer (BOOT) agreements"(Ernst \& Young 1994 hal 4)

Tujuan dan proses privatisasi tidak hanya sekedar mengurangi peranan pemerintah semata, akan tetapi prosesnya dapat dilakukan dengan menjual sahamnya kepada para investor swasta melalui pasar modal biasa yang dikenal dengan go public, atau melalui penawaran umum suatu perusahaan melalui pasar modal atau bursa saham (Initial Public Stock Offering).

Privatsisasi yang dilakukan pemerintah tidak berarti harus menghilangkan peran pemerintah sebagai stabilisator karena itu intervensi yang dilakukan pemerintah adalah untuk mencegah terjadinya kegiatan monopoli serta untuk menjamin ketersediaan barang di masyarakat.

\section{Pengembangan Model Privatisasi}

Dalam proses privatisasi BUMN, pemerintah bukanlah satu-satunya pihak yang terkait. Ada beberapa pihak -pihak yang terkait sepertia yang dikemukakan oleh Ernst \& Young yaitu, para pegawai pemerintah, manajer, pekerja dan politisi seperti yang dikemukakan dalam gambar dibawah ini:

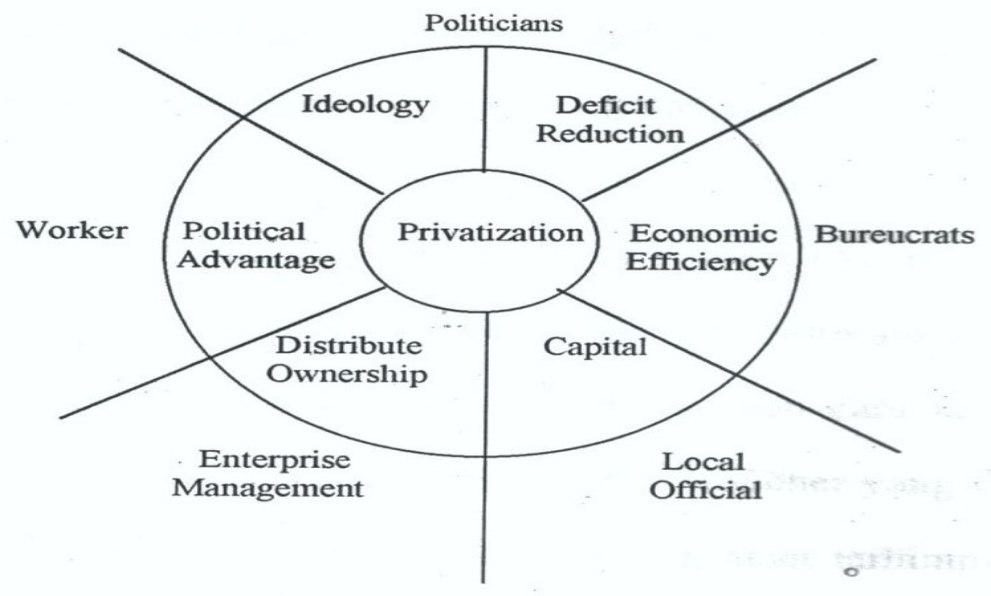

Sumber : Ernst \& Young, Privatization, (New York). Hal. 10

Pihak-pihak yang mempunyai kepentingan ( Stakeholder) dalam privatisasi pasti mempunyai kepentingan (interest) yang berbeda-beda. Pemerintah pusat dan pegawai lokal (local officials) berkepentingan dalam mengurangi defisit anggaran pendapatan dan belanja Negara. 
Dengan melakukan penjualan saham perusahaan negara akan memperoleh pemasukan yang dapat mengatasi defisit keuangan. Sementara kalangan politisi, birokrat dan pegawai pada pemerintahan ada kepentingan dari sudut politik dan ekonomi. Dari sudut ideologis para politikus melihat bahwa organisasi pemerintah terlalu besar hal ini menjadi beban yang berakibat lambannya organisasi tersebut. Di sektor swasta akan lebih efisien dan aktif secara ekonomis mengelola jalannya perekonomian dibandingkan dengan sektor pemerintah (state). Dengan privatisasi ini tentunya para politisi akan mendapatkan dukungan dan manfaat dari para pemilih yang memperoleh keuntungan dengan diadakanya privatisasi BUMN atau State Own Companies (SOEs).

Di lain pihak pekerja perusahaan tersebut ada kesempatan untuk mendapatkan saham (distribution of ownership) yaitu dimana perusahaan yang diprivatisasikan akan menjual kepada mereka dengan cara khusus, misalnya dengan diadakan diskon harga atau memperoleh voucher yang bisa ditukarkan dengan saham. Dengan cara seperti itu tentunya akan terhimpun modal atau capital dari para investor baru maupun dari para pembeli saham sebagai akibatnya dana tersebut akan digunakan bagi pengembangan usaha perusahaan yang di privatisasikan.

Pengembangan investasi dengan dana dari pasar modal melalui penjualan saham Badan Usaha Milik Negara (BUMN) merupakan cara yang baik bagi Badan Usaha Milik Negara (BUMN) itu sendiri begitu pula bagi dunia pasar modal, selain itu akan bermanfaat pula bagi semua anggota masyarakat. Dengan telah "go Public" maka Badan Usaha Milik Negara (BUMN) tersebut pengelolaanya dilakukan secara profisional, karena merupakan tuntutan para investor.

Bagi masyarakat umum, penjualan saham berarti semangkin bertambahnya kesempatan masyarakat yang berpenghasilan menengah ke bawah untuk turut memiliki saham Badan Usaha Milik Negara (BUMN) sebagai sarana alternatif dalam melakukan investasi yang menguntungkan. Kondisi perekonomian suatu negara akan sangat mempengaruhi berhasilnya program privatisasi. Bila kita melihat inggris dalam melakukan privatisasi. Sebaliknya Indonesia pada saat ini kondisi ekonomi yang sangat lemah telah menimbulkan terjadinya distorsi yang panjang antara kepentingan pemerintah di suatu sisi dengan kepentingan swasta dan masyarakat di sisi lain. Hal ini juga karena tidak kuatnya fundamental perekonomian Indonesia, apalagi dengan kondisi politik yang juga tidak menentu.

Program privatisasi di beberapa negara tidak hanya terbentuk pada satu pola mekanisme saja, melainkan ada banyak cara di dalam melaksanakan program privatisasi, termasuk dengan menggunakan metode penjualan "Voucher" seperti yang dilakukan di Cekoslawakia. Masyarakat membeli dengan harga nominal dan kemudian dapat ditukarkan dengan saham perusahaan yang diprivatisasi. Metode yang dilakukan ini dapat mendorong terjadinya partisipasi aktif di masyarakat serta mencegah terjadinya kemungkinan monopoli baru atas penjualan saham

Privatisasi di beberapa negara memiliki cirri masing-masing. Di Chili program privatisasi yang dilakukan oleh pemerintahnya yaitu melalui pola divestasi dimana pelelangan terhadap saham-saham dari berbagai perusahaan-perusahaan yang di privatisasi State Owned Enterprises (SOEs-nya). Namun cara ini kemudian berubah, dengan menjual saham-saham SOEs-nya melalui pasar modal, seperti yang terjadi dikebanyakan Negara-negara maju. 
Penjualan saham BUMN yang kinerjanya positif, berarti pemerintah akan merugikan Negara. BUMN yang mempunyai kinerja positif berarti menjadi sumber pemasukan keuangan Negara. Bila diprivatisasi ini berarti akan mengurangi sumber pemasukan Negara. Pihak swasta hanya akan membeli asset Badan Usaha Milik Negara (BUMN) yang menguntungkan.

\section{Model Privatisasi di Beberapa Negara}

Untuk melihat sejauh mana penerapan kebijakan privatisasi dibeberapa Negara ada baiknya kita melihat perbandingan terhadap sejumlah Negara yang menjalankan program privatisasi. Negara-negara yang dimaksud antara lain : Inggris, Singapura, Polandia serta Filipina.

\section{Inggris}

Sebelum pemerintah PM. Margaret Thatcher berkuasa sistem perekonomian Inggris di dominasi oleh peranan negara yang begitu besar, dimana mereka memiliki hak monopoli, terutama pada sektor-sektor transportasi, komunikasi dan sektor energi. Kondisi tersebut menyebabkan kesulitan dalam keuangan bagi pemerintah Inggris. Dalam kondisi kesulitan tersebut langkah kebijaksanaan yang dilakukan pertama adalah dengan mengadakan reformasi ekonomi. Salah satunya dengan melaksanakan kebijaksanaan program privatisasi bagi perusahaan-perusahaan BUMN (State-Owned Enterprises) yang dapat dikatakan berhasil dengan baik.

Keberhasilan dalam melaksanakan program privatisasi pada periode 19791993 telah terbukti dengan diperolehnya dana tambahan bagi keuangan negara sebesar 55 miliar Poundsterling dari hasil penjualan beberapa saham BUMN (SOEs), seperti British Telecom (BT)---emisi saham global terbesar dunia, yang oversubscribed sampai Sembilan kali lipat --- British Aerospaces, Associated British Ports, British Airports Authority, British Gas, dan beberapa perusahaan utilitas lainnya di Inggris. Program privatisasi telah menjadi model bagi Negara-negara lain didalam melaksanakan kebijakan program privatisasi, yaitu dengan mengadakan penjualan saham perusahaan Negara. Kebijaksanaan tersebut ia lakukan karena ia percaya benar pada mekanisme pasar dalam menjalankan roda perekonomian Inggris. Selain itu pengelolaan ekonomi yang tidak efesien dan peningkatan anggaran pemerintah oleh pemerintah sebelumnya. Adapun alasan lainnya adalah persaingan politik yang sudah lama antara Partai Buruh dan Partai Konservatif.

Sedangkan sasaran kebijakan reformasi ekonomi Inggris terdiri dari :

1. Membatasi kekuasaan dan pengaruh serikat buruh dari sector public,

2. Mengurangi peranan pemerintah,

3. Menyebar luaskan kepemilikan saham bagi masyarakat banyak,

4. Meningkatkan efisiensi dari sector usaha public,

5. Membangkitkan kompetisi

Adapun ruang lingkup kebijakan privatisasi pemerintah Inggris, seperti yang dikatakan oleh Dunn and Smith Tahun, 1990: 34 adalah sebagai berikut :

a. De-nasionalisation-by the sale of publicaly owned assets and equity (shares) to the private sector. e.g. British Rail Hotels, British Telecom, British Gas. 
b. Contracting out-subcontracting the provision of government finances goods and services to private contractors, e.g. refuse collection, hospital cleaning.

c. De-regulation-removing inhibitions and regulatory restrictions on enterprise and competition, e.g. the opticians dispensing monopoly, coach transport regulations.

Keberhasilan tersebut juga dapat dilihat dari adanya pemberian subsidi sebesar 3 miliar poundsterling pertahun bagi BUMN Inggris menjadi penghasil pajak sebesar 700.000 pegawai BUMN berubah status menjadi pegawai swasta dengan sekitar $90 \%$ diantaranya memiliki saham perusahaan di tempat mereka bekerja.

Kebijakan tersebut telah berubah pula pelayanan pada masyarakat dan terjadinya penurunan tariff. Britis Gas turun sekitar $28 \%$ begitu pula tarif pulsa telepon British Telecom turun sebesar 27\% Jumlah telepon umum meningkat 45\% dan tingkat keterpanggilan 96\% ketimbang 77\% sebelum dicatatkan ke bursa. Privatisasi atau Swastanisasi BUMN Inggris memberikan manfaat pula bagi para pensiunan dengan memperoleh tariff khusus dari British Telekom dengan memberikan tarif khusus $50 \%$.

\section{Singapura}

Kebijakan privatisasi di Singapura merupakan kebijakan yang cukup berbeda dibandingkan dengan negara-negara lain, hal ini karena pegawai pemerintah merupakan motor penggerak pertumbuhan dan kemajuan ekonomi negara tersebut. Bahkan mereka telah membuktikan kemampuannya membawa negara Singapura menjadi salah satu negara industri baru di dunia (Newly Industrialise Countries $(N I C s)$.

Privatisasi perusahaan Negara (SOEs) di Singapura dalam arti pengurangan peranan pemerintah dalam bidang ekonomi merupakan fenomena yang baru bagi Negara tersebut dalam melakukan privatisasi. BUMN (SOEs) memegang peranan yang cukup besar dan berpengaruh terhadap perekonomian modern Singapura. Akan tetapi dibeberapa Negara yang melakukan kebijakan privatisasi antara lain Singapura dan Poladia, swasta merupakan mesin pertumbuhan, sedangkan di Singapura peranan pemerintah merupakan kekuatan dibalik kesuksesan pertumbuhan ekonomi.

Keberhasilan peranan pemerintah Singapura dalam perekonomian tentunya tidak bisa dilepas dari latar blakang sejarahnya. Singapura sejak 1959 dikuasai oleh the People's Action Party (PAP). Beberapa alasan dasar bagi kebijakan intervensi pemerintah adalah sebagai berikut:

1. Faktor sejarah dari masa colonial hingga kemerdekaan (1819-1959), dan pemisahan dari Malaysia tahun 1965.

2. Latar blakang sebagai pelabuhan enterpot, dan penduduk yang terdiri para pendatang dari berbagai etnik, terbatasnya pasar dalam negeri dan terbatasnya sumber daya alam.

Selain hal tersebut di atas keadaan ekonomi yang bersifat import oriented, devaluasi Poundsterling, konfrontasi dengan Indonesia dan penarikan militer Inggris, semua itu menimbulkan sense of crisis dari para pimpinan PAP yang memerintah Singapura. Pemerintah percaya bahwa peran pemerintah dalam berbagai 
aspek perekonomian merupakan suatu keharusan demi kelangsungan politik dan ekonomi Negara Singapura.

Dapat dikatakan bahwa dasar intervensi Negara terhadap perusahaan Negara dan perekonomian di Singapura disamping berdasarkan teori ekonomi, juga berdasarkan kondisi social ekonomi dan sejarah Negara Singapura dari masa sebelum kemerdekaan hingga kemerdekaannya. Faktor lainnya adalah orientasi pembangunan dari para pimpinan yang jujur serta para pegawai pemerintah yang mempunyai visi dan misi sebagai pemimpin dalam sector pemerintahan.

Setelah berlangsung sekitar tiga decade peranan pemerintah dalam menjalankan roda perekonomian, ada keinginan untuk mengurangi perannanya. Dalam implementasinya bentuk program privatisasi yang diterapkan semua dating dari kehendak pemerintah dan bukan dari pihak swasta. Semua itu merupakan jawaban atas keberatan dari kamar dagang dan Industri atas kompetisi yang tidak adil dan hambatan terhadap perkembangan pengusaha local. Program privatisasi BUMN ini merupakan sebagian dari skema pengurangan peranan pemerintah pada sector ekonomi.

Pada bulan maret 1985, rencana program privatisasi secara resmi diumumkan di Parlemen, disampaikan bahwa pembangunan ekonomi seharusnya digerakan oleh sector swasta, dan bukan pada Negara. Adapun keputusan ini didasarkan pada empat macam keberatan yaitu :

Kebertatan dari perwakilan pengusaha yang menganggap bahwa pemerintah terlalu dominan dalam sector ekonomi sehingga local entrepereneur tidak berkembang. Kesulitan ekonomi akibat dampak oleh kontraksi likuiditas. Reformasi sector public telah mengakibatkan surplus likuiditas yang diakumulasi oleh beberapa statutory boards, sehingga oleh karena itu perlu pengurangan peran pemerintah yang menghasilkan surplus likuiditas tersebut.

Keinginan untuk mengontrol system manajemen perusahaan Negara yang dilakukan oleh tujuh orang Direktur dan lembaga konsultan yang mengawasi lebih dari 600 GLCs. Teknologi tinggi yang ditangani oleh beberapa perusahaan Negara akan lebih menguntungkan bila dikelola oleh pihak swasta karena kebebasan dan spirit kewirausahaan yang besar dimiliki oleh swasta. Privatisasi di Singapura dilaksanakan secara bertahap. Pertama adalah "partial privatization", yaitu penjualan subsidiary company yang dimiliki oleh Negara. Kedua "further privatization", yaitu penjualan sebagian saham perusahaan yang diswastakan. Ketiga, "effective privatization", yaitu penjualan saham dan pelepasan hak control atas semua kegiatan. Negara melepas lebih dari 50\% saham kepada investor swasta. Keempat, "total privatization", melepasakan diri dari kepemilikan dan dalam fungsi melakukan control atas manajemen perusahaan. Semua proses dan perencanaan privatisasi ini disusun oleh PSDC semacam lembaga privatisasi di Singapura dimana secara prinsipil harus disetujui oleh Menteri Keuangan.

PSDC melakukan privatisasi perusahaan negara dengan beberapa alasan yaitu :

1. Menyerahkan kegiatan perdagangan yang tidak lagi dibutuhkan dimana seharusnya dikelola oleh sektor swasta.

2. Memperluas dan mengembangkan bursa saham.

3. Menghindarkan atau mengurangi persaingan dengan sector swasta. 
PSDC dalam laporannya pada tahun 1987, ada empat bentuk utama dari privatisasi yaitu :

1. Privatisasi kepemilikan yaitu penjualan asset atau saham

2. Privatisasi produksi yaitu pemerintah membeli barang dan jasa dibandingkan memproduksi sendiri.

3. Privatisasi pembiayaan, pemerintah bersandar pada sisi harga barang dan jasa daripada pengenaan pajak untuk membiayai operasi perusahaan.

4. Liberalisasi dan deregulasi dimana kompetisi dalam dan dengan sector swasta melalui pengurangan atau penghapusan peraturan oleh pemerintah.

Privatisasi di Singapura dilakukan bukan untuk mendapatkan dana bagi pemerintah, karena Singapura tidak dalam kesulitan keuangan. Privatisasi dilakukan dengan tujuan untuk mendemokrasikan kepemilikan saham. Privatisasi SOEs dilakukan pemerintah dengan pertimbangan efisiensi ekonomi. Selain itu perusahaan yang di privatisasi adalah perusahaan yang mengelola sektor industri dalam kategori yang memproduksi public goods.

Selanjutnya dari aspek ekonomis maka program privatisasi di Singapura mempunyai fungsi :

1. Memotivasi untuk memaksimalkan keuntungan.

2. Merangsang untuk melakukan efisiensi dalam pengelolaan usaha, dan pengembangan teknologi.

Sedangkan dimensi politik dari privatisasi di Singapura adalah pendemokrasian kepemilikan saham. Salah satu sasaran privatisasi adalah dalam upaya mewujudkan kinerja positif pada perusahaan Negara. Pengurangan intervensi pemerintah melalui program privatisasi di Singapura tidak memberikan dampak yang berarti pada system perekonomian mereka. Privatisasi lebih banyak memberikan kesempatan kepada swasta untuk ikut menikmati kemajuan dan keuntungan yang diperoleh perusahaan negara Singapura.

Program restrukturisasi SOEs di Singapura akan terus berjalan dan diharapkan akan sukses berdasarkan pola dan triminologi pemerintah. Sektor swasta yang diharapkan sebagai motor penggerak pembangunan ekonomi akan difungsikan akan tetapi dengan sumber kekuatan yang berasal dari sektor publik (Negara).

\section{Polandia}

Privatisasi di Polandia merupakan suatu gambaran program privatisasi yang dilaksanakan di Negara-negara Eropa Timur, dimana system ekonomi yang dikendalikan oleh Negara secara sentral atau terpusat. Dengan runtuhnya beberapa Negara komunis pada akhir tahun 1989, program privatisasi di Negara-negara Eropa Timur menjadi topic yang penting. Situasi di Polandia dengan dilakukannya privatisasi bukan saja pengalihan kegiatan perekonomian dari negara kepada swasta akan tetapi juga merupakan perubahan yang cukup mendasar, di mana system ekonomi negara yang tadinya dikendalikan oleh negara menjadi perekonomian berdasarkan mekanisme pasar.

Perusahaan Negara (SOEs) yang didirikan oleh pemerintah menganut struktur perusahaan Negara dan merupakan bagian birokrasi pemerintah yang tujuannya melaksankan program-program pemerintah. Perusahaan Negara yang dikendalikan oleh birokrat dan ditunjuk oleh pemerintah disebut dengan 
"nomenklatura" Dengan struktur yang terpusat dan dengan kondisi masyarakat yang tidak mendukung untuk kemajuan sector ekonomi, mengakibatkan kekacauan system perekonomian Polandia. Dalam mengatasi sistem ekonomi yang kacau, pemerintah melakukan serangkaian kebijakan, yaitu dengan pembaharuan ekonomi (economic reform). Hal ini yang terpenting dalam pembaharuan ekonomi ini adalah apa yang disebut sebagai "BALCEROWICZ FILAIV", dimana berisi aspek-aspek makro ekonomi seperti pembatasan kredit, gaji, upah, dan pengurangan subsidi yang disusun untuk mengatasi inflasi.

Dengan telah disusunya Rencana Undang-undang (RUU) mengenai privatisasi pada tahun 1990, yaitu "The Privatization of State Enterprises" and on "The Council of National Capital and the Agency for Ownership Transformations" dimana keudian disetujui oleh Parlemen pada tanggal 13 Juli 1990. Bentuk privatisasi dalam Undang-Undang tersebut dapat dilakukan dalam 2 cara yaitu :

1. Penjualan saham perusahaan negara yang disebut dengan capital privatization ;

2. Penutupan perusahaan negara dan menjual assetnya yang disebut dengan privatization by liquidation.

Penjualan saham perusahaan Negara (BUMN) Polandia dilakukan dalam 2 tahap yaitu :

1. Transformasi perusahaan (corporation), yaitu transformasi perusahaan menjadi bentuk perusahaan dengan saham (joint-stock company).

2. Penjualan saham ; Perusahaan menjual sahamnya kepada pembeli yang potensil, yaitu Polandia, karyawan perusahaan yang diprivatisasikan, investor institusional lokal, dan investor asing.

Privatisasi dengan bentuk likuiditas perusahaan Negara dilakukan dengan penjualan asset perusahaan Negara kepada masyarakat. Privatisasi Polandia tidak membatasi pertumbuhan dan perkembangan usaha swasta dalam melakukan investasi melalui pembelian saham atau asset perusahaan Negara hal ini dimungkinkan karena dilindungi oleh undang-undang. Selanjutnya dalam undangundang tersebut menetapkan pula pembentukan Ministry of Property Transformation menggantikan Menteri Keuangan sebagai pejabat tunggal untuk mengawasi pengalihan perusahaan Negara menjadi perusahaan yang memiliki saham-saham.

Pada umumnya program privatisasi di Polandia mencontoh program privatisasi di Ingris, dengan cara menjual sebagian atau seluruh asset atau saham perusahaan Negara. Pelaksanaanya dilakukan dengan membagikan 'voucer' secara Cuma-Cuma kepada semua warga Polandia dimana dapat ditukarkan dengan sahamsaham perusahaan Negara yang diprivatisasikan. Pelaksanaan privatisasi perusahaan Negara dapat berasal dari manajemen perusahaan, buruh, atau organ pendiri yang ditetapkan oleh pemerintah. Dalam pembagian jumlah saham sebesar 20 persen disertai potongan harga sebesar 50 persen dari harga saham perdana. Direncanakan sekitar $10 \mathrm{~s} / \mathrm{d} 20$ persen saham perusahaan yang diprivatisasikan akan diberikan secara cuma-cuma kepada masyarakat. Selain itu ada kebijakan bagi investor asing hanya dapat membeli saham perusahaan yang diprivatisasikan maksimal sebesar 10 persen, sedangkan bila ingin ditingkatkan maka wewenangnya ada pada The Agency for Foreign Investments. 
Privatisasi di Polandia dilaksanakan dengan arahan yang telah ditetapkan secara terperinci dan transparan. Dalam pelaksanannya tiap-tiap sector bertanggung jawab dan mengetahui posisi masing-masing dalam melakukan privatisasi perusahaan negara.

\section{Filipina}

Pelaksanaan privatisasi di Filipina hampir mirip dengan kebijakan privatisasi yang dilakukan oleh pemerintah Indonesia terhadap sejumlah BUMN. Privatisasi yang dilakukan bersifat kolektif yaitu melalui penjualan berbagai usaha milik Negara yang bermasalah. Privatisasi di Filipina terutama kepada sejumlah industry semen melibatkan model IMF. Karena krisis ekonomi yang melanda Filipina beberapa waktu lalu menyebabkan industry semen yang sebagian dikuasai oleh pemerintah dialihkan kepada swasta asing yang juga telah mengambil alih beberapa industry semen di Indonesia.

Sistem yang dilakukan adalah melalui penjualan langsung dengan melakukan penawaran terbuka, termasuk kepada swasta asing, Privatisasi yang dilakukan mengacu kepada kesepakatan IMF sebagai kesepakatan dalam rangka pemulihan ekonomi. Namun privatisasi yang dilakukan pada sejumlah industri semen di Filipina masih tergolong tinggi nilainya walaupun dari sisi teknologi sebagian besar industri semen di Filipina masih menggunakan wet process yaitu menggunakan proses basah. Penggunaan teknologi seperti ini sangat tidak efisien dan biaya produksinya cukup tinggi. Namun, harga penawaran yang dilakukan oleh swasta asing antara lain Heidelberger, Cemex dan Holcim masih tergolong tinggi yaitu mencapai USD 114,5/ton.

Sementara privatisasi industry semen di Indonesia dengan melakukan penjualan saham langsung seperti di Filipina antara lain PT ITP yang menggunakan teknologi Dry Process merupakan teknologinyang sangat bagus dibandingkan dengan Wet Process. Akan tetapi nilai jual yang ditawarkan kepada asing hanya mencapai USD 47/ton, jauh lebih tinggi dibandingkan denagn penawaran yang dilakukan Filipina.

Dengan melihat pola privatisasi dibeberapa negara maka dapat digambarkan bahwa salah satu tujuan dari privatisasi adalah agar perusahaan pemerintah dapat bekerja secara efisien. Akan tetapi langkah yang dilakukan sebelum privatisasi terlebih dahulu melalui pola korporatisasi hal ini agar perusahaan pemerintah tersebut tidak hanya bekerja secara efisien akan tetapi kompetitif, selanjutnya bila memang masih dibutuhkan dana dan secara manajemen layak, maka kegiatan privatisasi dapat dilakukan. Program privatisasi sebaiknya merupakan langkah terakhir bila memang pemerintah sangat memerlukan dana. Karena dengan melakukan program privatisasi berbagai aspek perlu dikaji baik aspek social maupun keadilan bagi masyarakat.

\section{E. Privatisasi BUMN Indonesia : Sebuah kebutuhan}

Privatisasi BUMN menjadi menarik untuk membantu pemerintah dalam mendapatkan modal kerja jangka pendek, salah satu argumentasi yang mengemuka adalah privatisasi dapat menghasilkan penjualan, pada sisi lain mendorong akan mendorong efisiensi pengeloalaan BUMN. Atas pertimbangan tersebut maka 
pemerintah melihat kinerja BUMN dalam berbagai kategori, muli dari kategori tidak sehat sampai pada kategori sehat (layak). Ada beberapa BUMN yang dinilai sehat atau sehat sekali, tetapi juga tidak sedikit BUMN yang masuk dalam kategori tidak sehat untuk meningkatkan kinerja sejumlah BUMN yang termasuk kategori tidak sehat, pemerintah mengeluarkan pokok-pokok kebijakan bagi penyehatan BUMN.

BUMN yang tergolong sehat atau sehat sekali dapat dikembangakan lebih lanjut dengan menempuh enam cara yakni (a) melakukan konsolidasi, (b) melakukan penggabungan (merger), (c) memasyarakatkan sahamnya (go-public), (d) menerima pernyataan langsung (private placement), (e) melakukan Kerja Sama Operasi (KSO), (f) membentuk perusahaan patungan (joint Venture).

Sementara industr BUMN yang tergolong kurang sehat (KS)' dapat diperbaiki kinerjanya dengan melakukan penataan internal melalui berbagai cara yang ditempuh antara lain (a) melakukan restrukturisasi permodalan, (b) melakukan penyederhanaan struktur organisasi, (c) melakukan penggabungan, baik antara BUMN, (d) memecahkan perusahaan menjadi beberapa BUMN, (e) mengikutsertakan partisipasi masyarakat melalui penyertaan langsung, (f) melakukan kontrak manajemen.

Adapun BUMN yang masuk kategori "Tidak Sehat (TS)" dapat ditempuh langkah sebagai berikut yaitu (a) dilakukan penyehatan sesuai dengan kedua pola tersebut di atas, (b) dijual, atau (c) dilikuidasi. Langkah pemerintah dalam memperbaiki BUMN melalui INPRES No 5/1988, sebenarnya cukup efektif dan terarah. Beberapa BUMN yang tidak sehat dan tidak dapat dipertahankan akhirnya dilikuidasi dan sebagian lagi yang demerger.

Kebijakan restrukturisasi secara bertahap yang dilakukan pemerintah mencerminkan adanya keinginan untuk memperbaiki performance BUMN yang kurang baik. Penerapan kebijakan tersebut merupakan cara terbaik tanpa harus mengorbankan BUMN yang memang masih dapat dipertahankan. Namun, kebijakan tersebut tidak dapat bertahan lama dikarenakan krisis ekonomi yang menimpa Indonesia pada akhir tahun 1997. Kejadian ini memaksa pemerintah untuk mencurahkan segenap perhatiannya atas sejumlah BUMN yang terkena dampak krisis.

Untuk mengantisipasi keterpurukan BUMN, maka pemerintah melalui kesepakatan IMF yang tertuang dalam lima puluh butir kesepakatan, yang ditandatangani pada akhir tahun 1997 mengharuskan pemerintah mengambil sikap tegas dengan melakukan restrukturisasi structural secara menyeluruh. Sebagai tindak lanjut dari kesepakatan pemerintah dengan IMF maka pemerintah mengeluarkan PP No 98/1999 yang menugaskan Meneg BUMN untuk melakukan upaya privatisasi terhadap BUMN yang dianggap bermasalah.

Konsep privatisasi yang dilakukan pemerintah, selain merupakan realitas atas kondisi yang terjadi, juga merupakan bagian dari kebijakan deregulasi secara umum, dan lazimnya merupakan kelanjutan deregulasi itu sendiri. Seperti yang dikemukakan Savas, (1992:hal 25), menyebutkan, privatisasi merupakan peran swasta dalam pemilikan aktiva atau kekayaan ekonomi.

Kebijakan privatisasi di Indonesia merupakan salah satu alternative dalam merespon kondisi perekonomian Negara saat ini. Namun, perlu diakui pula bahwa penerapan privatisasi terhadap BUMN dan perusahaan lainnya dimana Negara 
member penyertaan saham tidak diikuti dengan UU privatisasi. Karena itu konsep privatisasi yang dilaksanakan pemerintah berdasarkan PP No.1/2000 terkesan interpretative, karena itu tidak mengherankan kalau privatisasi saat ini menimbulkan pertanyaan bahkan polemic dari public terutama terhadap kebijakan yang ditujukan kepada industry semen yang di privatisasi. Oleh karena itu privatisasi yang dilakukan pemerintah berada pada kondisi dimana ekonomi Indonesia mengalami keterpurukan, menyebabkan kebijakan privatisasi seolah-olah tidak popular, terutama dimata public. Bahkan kebijakan privatisasi dianggap lebih mementingkan kepentingan jangka pendek. Upaya menutupi defisit anggaran pemerintah yang terus membengkak, merupakan salah satu alternatif dan alasan bagi pemerintah saat ini melalui program privatisasi.

Kebijakan privatisasi hendaknya mempertimbangkan rasa keadilan masyarakat dengan mengutamakan asas transparasi serta mempertimbangkan aspek kepentingan jangka panjang termasuk ekternalitasnya yang berkaitan dengan kepentingan publik. Sejalan dengan pelaksanaan privatisasi tersebut ada beberapa hal yang perlu dipertimbangkan, seperti yang dikemukakan oleh Didik J. Rachbini: (lihat Harian Umum Republika tanggal 6 Maret 2002) bahwa politik privatisasi tergantung pada dua faktor, diluar soal keterkaitan dengan tekanan lembaga internasional seperti IMF. Dua acuan rasional bagaimana keputusan privatisasi dilaksanakan. Faktor pertama adalah kinerja perusahaan BUMN itu sendiri. Faktor kedua adalah ekternalitas (manfaat) terhadap ekonomi dan masyarakat secara lebih luas. Sementara dasar pertimbangan terhadap BUMN yang akan diprivatisasi maupun yang perlu dipertahankan dapat dilihat dalam skema di bawah ini :.

\begin{tabular}{|c|c|c|}
\hline $\begin{array}{c}\text { Kinerja BUMN } \\
\text { (Merugi atau Untung) }\end{array}$ & $\begin{array}{c}\text { Dampak Sosial Ekonomi } \\
\text { (Eksternalitas) }\end{array}$ & $\begin{array}{c}\text { Kebijakan Yang Perlu } \\
\text { Dilakukam Oleh } \\
\text { Pemerintah }\end{array}$ \\
\hline+ & - & Jual \\
+ & + & $\begin{array}{c}\text { Jual sebagian kecil/ } \\
\text { Pertahankan } \\
\text { Korporasi }\end{array}$ \\
- & + & Likuidasi \\
- & - & \\
\hline
\end{tabular}

Keterangan :

$+\quad$ : Untung

- $\quad$ : Merugi

Dari keterangan di atas, maka ada empat alternatif kebijakan terhadap BUMN yang perlu ditempuh berkaitan dengan kinerjanya maupun terhadap dampak social dan ekonomi yang dirasakan masyarakat secara langsung. Alternatif pertama, jika kinerja BUMN rendah, tetapi ada factor eksternalitas yang tinggi, maka pemerintah perlu melakukan korporatisasi agar kinerjanya meningkat. Masyarakat 
sangat tergantung pada produk BUMN tersebut sehingga tidak mungkin melakukan likuidasi terhadapnya. Faktor kepentingan masyarakat menjadi pertimbangan penting agar BUMN tidak dilikuidasi. Pemerintah melakukan kontrak manajemen dan usaha penekan pengganti pasar terhadap direksi BUMN ini.

Alternatif kedua, jika kinerja BUMN baik dan eksternalitasnya baik, maka ada dua kemungkinan, yakni pertahankan atau sebagian saja dijual. Privatisasi terhadap BUMN yang mempunyai manfaat besar bagi masyarakat dan Negara tidak harus dijual. Manfaat tersebut, misalnya dalam bentuk manfaat produk yang dihasilkan, pendapatan Negara, deviden, dan sebaginya. Masuk ke pasar modal pun tidak dengan cara menjual dalam porsi yang besar, tetapi cukup dengan porsi terbatas.

Alternatif ketiga, jika perusahaan BUMN tidak mempunyai kinerja yang baik dan ekternalitasnya rendah, maka BUMN ini sebaiknya dilikuidasi. Alternatif keempat, jika kinerja BUMN baik dan eksternalitasnya rendah, maka diusahakan agar dijual melalui pasar modal atau go public. Keputusan ini dimaksudkan agar BUMN tersebut bersaing secara langsung dengan perusahaan swasta sejenis. Produl BUMN ini biasanya sudah dapat digantikan oleh pihak swasta.

Pilihan kebijakan privatisasi BUMN sebagai model pembiayaan pembangunan dapat dilakukan oleh pemerintah sejalan dengan perbaikan kondisi ekonomi domestik yang diperkirakan akan tumbuh pada tahun 2018 dan 2019. Kondisi ini pula dperkuat dengan perkiraan akan membaiknya perekonomian dunia disertai meningkatnya ekspor Indonesia di bererapa negara tujuan ekspor. Prediksi pertumbuahan ekonomi tahun 2018 mencapai 5.3\% harus dibarengi dengan skema pembiayaan tanpa harus bergantung pada utang luar negeri'

\section{Simpulan}

Kebutuhan anggaran yang disediakan oleh pemerintah dalam melaksanakan pembangunan terus meningkat dari tahun ke tahun. Peningkatan ini sejalan dengan meningkatnya program pembangunan serta peningkatan kesejahteraan masyarakat. Bagi pemerntah peningkatan beban anggaran ini berdampak pada kemampuan penyediaan keuangan negara yang dalam waktu tiga tahun terahir ini justru mengalami penurunan

Keterbatasan sumber anggaran dan pendapatan negara dan ketersediaan tabungan dalam negeri yang tidak memadai dari kebututuhan pembangunan, memaksa pemerntah untuk melakukan penambahan pinjaman luar ngeri yang terus mengalaami peningkatan cukup tinggi. Diperlukan disain kebijakan untuk mengatasi pembiayaan pembangunan yang terlalu mengandalkan pada utang luar negeri

Privatisasi BUMN dapat menjadi alternatif pembiayaan dalam negeri, selain karena aset dan omset BUMN yang cukup besar juga perputaran usaha cukup besar, inilah pilihan yang perlu dpertimbangkan dengan mengembangkan model privatisasi yang terjadi pada beberapa negara maju dan berkembang. Model privatisasi atau pengembangan model baru bisa dilakukan sebagai alternatif pembiayaan pembangunan 


\section{Daftar Pusataka}

Ahmad Erani Yustika Prof. Dr, 2012. Ekonomi Kelembagaan: Pradigma, Kebijakan dan Teori, Erlangga Jakarta Indonesia

Clarke, Thomas and Pitelis, 1993 The Political economy of Privatization, Padstow, Corn wall

David L. Weimer, 1991 : Policy Analysis: Concepts and Practice, Prentice Hall UK London

Deliarnov, 2006 : Ekonomi Politik, Erlangga Jakarta Indonesia

Edwin L.Miller Jr, 2010. Mergers and Acquisitions : Panduan Merger dan Akuisisi, Kompas Gramedia Jakarta, Indonesia

Ernest and Young, 1994 Privatization: Investing in State - Owned Enterprises Arround the World, John Wiley and Sons Inc. USA

Riant Nugroho Dr, 2009 Public Policy: Konsep dan Analisis, Kompas Gramedia Indonesia

Savas, 1987 : Privatization The key to better Better Government, Chatham House Publishers New Jersey 
